UDC 378.147

DOI: $10.52534 / \mathrm{msu}-\mathrm{pp} .7(3) .2021 .29-38$

Iryna S. Sahaidak ${ }^{1^{*}}$, Tetiana M. Chorna ${ }^{1}$, Olena O. Balahura ${ }^{2}$, Valentyna P. Bykhovchenko ${ }^{3}$

${ }^{1}$ University of the State Fiscal Service of Ukraine

08205, 31 Universitetska Str., Irpin, Ukraine

${ }^{2}$ National Transport University

01010, 1 M. Omelyanovich-Pavlenko Str., Kyiv, Ukraine

${ }^{3}$ National University of Life and Environmental Sciences of Ukraine, 03041, 15 Heroiv Oborony Str., Kyiv, Ukraine

\title{
Specifics of Distance Learning in the Modern Ukrainian Educational Space: Practices of the Higher Education Institutions of Ukraine
}

\section{Article's History:}

Received: 15.05.2021

Revised: 20.06.2021

Accepted: 10.08.2021

\section{Suggested Citation:}

Sahaidak, I.S., Chorna, T.M., Balahura, O.O., \& Bykhovchenko, V.P. (2021). Specifics of distance learning in the modern Ukrainian educational space: Practices of the higher education institutions of Ukraine. Scientific Bulletin of Mukachevo State University. Series "Pedagogy and Psychology", 7(3), 29-38.

*Corresponding author

\begin{abstract}
Quarantine restrictions have increased the relevance of distance learning, and the level of information and communication technology development has made it possible for the Higher Education Institutions (HEIs) to switch to online mode, this being the optimal solution amid the pandemic. The object of this paper is to analyse the practical aspects of distance learning under quarantine and to identify the key factors affecting its efficiency. The assessment of the distant technologies use during the educational process and its efficiency was carried out by means of anonymous online questionnaire survey of the students from 4 higher education institutions: University of the State Fiscal Service of Ukraine, National Transport University, National University of Life and Environmental Sciences of Ukraine and Separated structural subdivision of the Kyiv College of Municipal Economy of The V.I. Vernadsky Taurida National University. The research has revealed the level of technical provision for distance learning; the level and practical experience of using distance technologies by the participants of the educational process was determined; the behavioural factors (students' attendance and teachers' adherence to the class schedule and thematic outlines) were examined; motivational factors of students' learning online were analysed; the most significant benefits of distance learning were examined; the higher education students' attitude to the blended and distance forms of learning was determined. It has been substantiated that distance learning organisation in the institution based on a single shared platform is a prerequisite for ensuring a highly effective online learning process. The practical value of the paper lies in the application of the survey results to enhance and increase the distance learning efficiency at the higher education institution level
\end{abstract}

Keywords: educational process organisation, online mode, quarantine, high school, questionnaires, online learning efficiency

\section{INTRODUCTION}

In recent years, information technology and the possibility of its use, namely the Internet, have provided favourable conditions for the development of the information society both in the world and in Ukraine. Modern information technologies have given an impulse to the digitalisation of the educational process: the introduction of distance learning in educational institutions. Thus, the core points of the National Informatisation Programme of Ukraine [1] state: "In the field of education ... active introduction of distance learning into the educational process is envisaged ..., which involves a significant part of the work with information, i.e., the perception, assimilation and communication 
between teacher and their students, by means of modern information technologies and computer-based telecommunications". It should be noted that distance learning is not a new form of education, but has already existed for many years, constantly improving and forming new information networks. Distance learning has been implemented in Ukraine for over ten years, and the approval of the Regulation on Distance Learning [2] has provided possibilities for its implementation in the educational process of Ukrainian institutions.

The COVID-19 pandemic, starting in 2019, has made it impossible for educational institutions to operate in the traditional format and, hence, has significantly intensified the introduction of distance learning technologies in the educational process. Attention should be drawn to the fact that the move to distance learning has been a huge challenge for all educational institutions in Ukraine, from schools to universities, as it has been necessary to start online classes in a short period of time, which not everyone has been ready for. Thus, the current situation has given the scientific and teaching community the incentive to actively investigate the practical application efficiency of the distance technologies in the teaching process of HEIs. For instance, the scholars E. Armstrong-Mensah and K. Ramsey-White presented the research results on the impact of the move to online learning on students and postgraduates: the academic difficulties among students and the unexpected benefits of distance learning were revealed [3]. S. Elfirdosi and M. Lahgar [4] share the research results on the assessment of distance learning in Moroccan universities. The research is primarily focused on studying the limitations of the platforms used to support online learning. Furthermore, the authors carried out a comparative analysis of distance learning in state and private universities during the quarantine period [4]. J. Stein and C. Graham in their studies argue that the practice of blended teaching and learning is most appropriate [5]. Meanwhile, Y. Nenko, N. Kubalna and Y. Snisarenko point out the lack of scientific coverage regarding the distance learning efficiency in Ukrainian HEIs [6].

When referring to the state and normative regulation practices it should be noted that currently its arrangement and introduction procedure is stated in the Regulations on the Distance Form of Full General Secondary Education approved by the Order No. 1115 of the Ministry of Education and Science of Ukraine on September 8, 2020 [7]. As for HEIs, according to the Law of Ukraine "On Education" [8], they have the autonomy based on their self-reliance, independence and decision-making responsibility for academic (educational), organisational, financial, personnel and other activity issues, carried out in accordance with the procedure and within the limits defined by law.

All those involved in the educational process now realise that there is no certainty as to what mode the next academic year will be as well as when, for how long and how often the need to move to online mode will arise. Therefore, the practical efficiency assessment of distance learning is an essential element for its further enhancement and the prevention of future mistakes.

The purpose of this study is to analyse the practical aspects of distance learning under quarantine and to determine the key factors that affect its effectiveness.

To achieve the said purpose, it is necessary to complete the following objectives:

- an analysis of the research covering different aspects of distance learning;

- a study of the distance learning arrangements in higher education institutions: University of the State Fiscal Service of Ukraine, National Transport University, National University of Life and Environmental Sciences and Separated structural subdivision of the Kyiv College of Municipal Economy of The V.I. Vernadsky Taurida National University;

- a study of the student's attitudes towards the organisation and the efficiency of distance learning.

\section{LITERATURE REVIEW}

As previously mentioned, the studies of both foreign and Ukrainian authors focus on the issues related to the development and implementation of distance technologies in the educational process. However, they can be divided into two categories - those published before the pandemic and those after its outbreak. The studies of the first group are more concerned with the definition of the distance learning / education terms; the analysis of the distance learning development stages; the world experience; the distance learning features and types; and provide information on the necessity of the education system's computerisation and the implementation of information technology in the teaching / learning process. L.V. Shtykhno analyses the world experience of distance education and outlines the major factors hindering the distance learning implementation in the educational process of Ukrainian institutions [9]. O.A. Panchenko focuses on the contradictions in distance education by presenting the sociological survey results regarding the level of familiarity with distance learning technologies, the possibilities to use them and the attitude to their implementation by teachers in the Prydniprovskyi region [10]. O.H. Korbut's study covers different models and technologies of distance learning as well as peculiarities of its implementation in the modern education system [11]. The article by L. Havrilova and Y. Katasonova "outlines the theoretical aspects of the distance education development in Ukraine, particularly its conceptual framework, and analyses the historical phases of the distance learning basic concepts formation. The concepts of "distance education" and "distance learning" were compared, and the related concepts of open education and blended learning were examined" [12].

The most recent studies by foreign and Ukrainian academics published since the pandemic outbreak (the second group) focus on the practical efficiency of the distance learning process at all educational levels. Thus, the published results of a research by UNESCO scholars on compelled online learning demonstrate the actual isolation of the majority of higher education students in cities [13]. 
These cities ("Learning cities") serve as a centre for the efficient mobilisation of educational resources and the use of modern technologies for online learning [14].

A joint monograph by V.V. Bondarenko and V.M. Kukharenko presents the overview of theoretical and methodological perspectives on the pressing issue for the Ukrainian educational system of implementing the educational process under quarantine; a scientific and methodical analysis as well as a research and practice analysis of the situation; a wide range of issues, problems and suggestions based on the actual pedagogical experience of the academic community is covered [15]. The authors A.A. Oleshko, O.V. Rovniahin and V.R. Hodz focus on the issues of online learning under the quarantine period: insufficient level of technical provision, limited access to the Internet, the lack of experience in information technologies among both teachers and students [16]. Meanwhile, the study by Y. Nazarenko, O. Syrbu and I. Kohut provides an analysis of the actions taken by the Government (under the UNDP project "Human Rights for Ukraine") in organising the educational process during the quarantine period, and also focuses on the educational and post-educational issues encountered by the educational process participants [17].

\section{MATERIALS AND METHODS}

A theoretical investigation (analysis of publications by Ukrainian and foreign academics, commentaries, interviews with high-level officials, forums) has resulted in a summary of the distance learning features and its implementation issues under quarantine. The obtained theoretical results provided the basis for the research area selection, the definition of its objective and main tasks. On the basis of theoretical works the empirical study object was defined, the topic was formulated and its separate elements were analysed, the results were carried out and summarised.

The research involved three processes: 1) data collection process; 2) research tools selection and development process; 3 ) sampling process. The data collection process in the research was ensured through a questionnaire survey aiming to determine students' attitudes towards the efficiency of distance learning implementation in HEIs. The key research tool was a questionnaire, with a total of 14 multiple-choice, closed-ended and open-ended questions, as well as questions with an evaluation scale. The questionnaire focused on the following issues: the level of technical provision for distance learning; the level and practical experience of using distance technologies by the participants of the educational process; behavioural factors (students' attendance and teachers' adherence to the class schedule and thematic outlines); students' motivation for learning; the most significant benefits of distance learning; the organisation level of distance learning in an educational institution (Table 1).

Table 1. Questionnaire structure used in the research process

\begin{tabular}{|c|c|c|}
\hline No. & Question & Type of response \\
\hline 1. & What educational institution do you represent? & $\begin{array}{l}\text { One option } \\
\text { from the suggested list }\end{array}$ \\
\hline 2. & $\begin{array}{l}\text { Did you have any experience of using distance technologies in your educational } \\
\text { institution before the quarantine was declared? }\end{array}$ & $\begin{array}{l}\text { One option } \\
\text { from the suggested list }\end{array}$ \\
\hline 3. & $\begin{array}{l}\text { What forms of education have you experienced during the quarantine period } \\
\text { (blended or distance learning)? }\end{array}$ & $\begin{array}{l}\text { One option } \\
\text { from the suggested list }\end{array}$ \\
\hline 4. & Which of the forms (blended or distance) is more effective for you? & $\begin{array}{l}\text { One option } \\
\text { from the suggested list }\end{array}$ \\
\hline 5. & $\begin{array}{l}\text { According to you, how relevant and necessary is distance learning under } \\
\text { current conditions? }\end{array}$ & $\begin{array}{l}\text { One option } \\
\text { from the suggested list }\end{array}$ \\
\hline 6. & What communication platforms did you use for distance learning? & $\begin{array}{l}\text { Several options } \\
\text { from the suggested list }\end{array}$ \\
\hline 7. & $\begin{array}{l}\text { What proportion of the students in your academic group (on average) actually } \\
\text { participate in the learning process according to the class schedule? Does it } \\
\text { depend on the specific subject / teacher? }\end{array}$ & $\begin{array}{l}\text { Several options } \\
\text { from the suggested list }\end{array}$ \\
\hline 8. & Do the teachers follow the schedule under distance working conditions? & $\begin{array}{l}\text { One option } \\
\text { from the suggested list }\end{array}$ \\
\hline 9. & $\begin{array}{l}\text { Do you consider the teachers' usage level of various communication forms to } \\
\text { be sufficient? }\end{array}$ & $\begin{array}{l}\text { One option } \\
\text { from the suggested list }+ \text { your } \\
\text { version of the response }\end{array}$ \\
\hline 10. & $\begin{array}{l}\text { How satisfied are you with the distance learning in your educational institution } \\
\text { under the quarantine conditions? }\end{array}$ & $\begin{array}{l}\text { Evaluation scale } \\
\quad(\text { from } 1 \text { to } 5)\end{array}$ \\
\hline 11. & According to you, what determines the distance learning efficiency? & $\begin{array}{l}\text { Several options } \\
\text { from the suggested list }+ \text { your } \\
\text { version of the response }\end{array}$ \\
\hline
\end{tabular}


Table 1, Continued

\begin{tabular}{c|c|c}
\hline No. & Question & Type of response \\
\hline 12. & According to you, what are the most significant benefits of distance learning? & $\begin{array}{c}\text { Several options } \\
\text { from the suggested list + your } \\
\text { version of the response }\end{array}$ \\
\hline 13. & $\begin{array}{r}\text { Did you practice self-education using distance learning technologies (e.g. } \\
\text { taking online courses, not necessarily related to studies, etc.)? }\end{array}$ & $\begin{array}{c}\text { One option } \\
\text { from the suggested list + your } \\
\text { version of the response }\end{array}$ \\
\hline 14. & $\begin{array}{r}\text { According to you, once the pandemic is over, will distance technologies remain } \\
\text { popular, or will their popularity wane? }\end{array}$ & Test \\
\hline
\end{tabular}

The questionnaire structure made it possible not only to consider the students' opinion regarding the educational process organisation and its high-quality provision both technologically and methodologically, but also to let the respondents make their own suggestions on the choice of platforms, the tasks selection, the teaching/learning materials quality, etc. The questionnaire was conducted in a selective manner, as only a certain proportion of the respondents were surveyed.

The assessment of the distance technologies use during the educational process and its efficiency was carried out by means of respondents' interviewing - students from 4 higher education institutions: University of the State Fiscal Service of Ukraine (hereinafter referred to as USFSU), National Transport University (hereinafter NTU), National University of Life and Environmental Sciences of Ukraine (hereinafter NUBiP) and Separated structural subdivision of the Kyiv College of Municipal Economy of V. I. Vernadsky Taurida National University (hereinafter SSS KCME V.I. Vernadsky TNU). To ensure the assessment objectivity, the survey covered over 400 participants (on average $100 \pm 2$ students from each educational institution). Meanwhile, students from many different groups, years of study and specialities were invited to participate in the online survey. The survey was held in February 2021, after a year of practical experience in online working mode. The survey was performed anonymously, in online mode, with the help of Google Forms, aiming to assess the overall current implementation level of distance learning and its efficiency, to reveal the major problems in the online learning arrangements.

\section{RESULTS AND DISCUSSION}

It is rather complicated to draw conclusions about the complete implementation of distance learning, especially in spring 2020. Distance learning is a certain system composed of 4 types of interconnected actors (Fig. 1). Apart from the immediate participants of the educational process - the student and the teacher - a smooth online learning process in HEIs is impossible without proper planning, appropriate curriculum development and various organisational issues (organiser's functions). The system administrator is responsible for ensuring the smooth functioning of the system, resolving technical issues and monitoring the system's performance statistics.
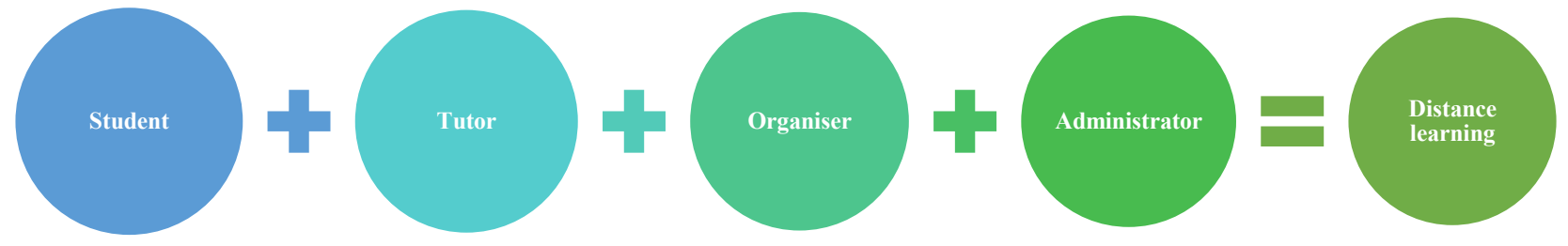

Figure 1. The components of a distance learning system

The imposition of quarantine across the entire territory of Ukraine in spring 2020 was sudden, and no one expected it to drag on. Consequently, each HEI chose different means of distance learning implementation. The distance learning system has been established at some institutions and has already been used to some extent, but mainly there has been no well-organised switch to any of the platforms. Thus, to send and check the assignments, and for the feedback purposes, the teachers used those communication platforms that they had access to and were able to work with independently. "Despite the level of electronic resources and distance learning platforms provision, all the teachers have encountered difficulties in online classes arrangement, providing for the teacher's e-presence, converting educational materials, receiving a feedback, defining the information supply channels, etc." [18]. It is therefore not surprising that the respondents' answers vary in the names of communicative platforms and social networks (Fig. 2). A significant proportion of respondents used Google Disk (43.2), Viber (49.3), Telegram (69.2), Moodle (66.4), etc. 


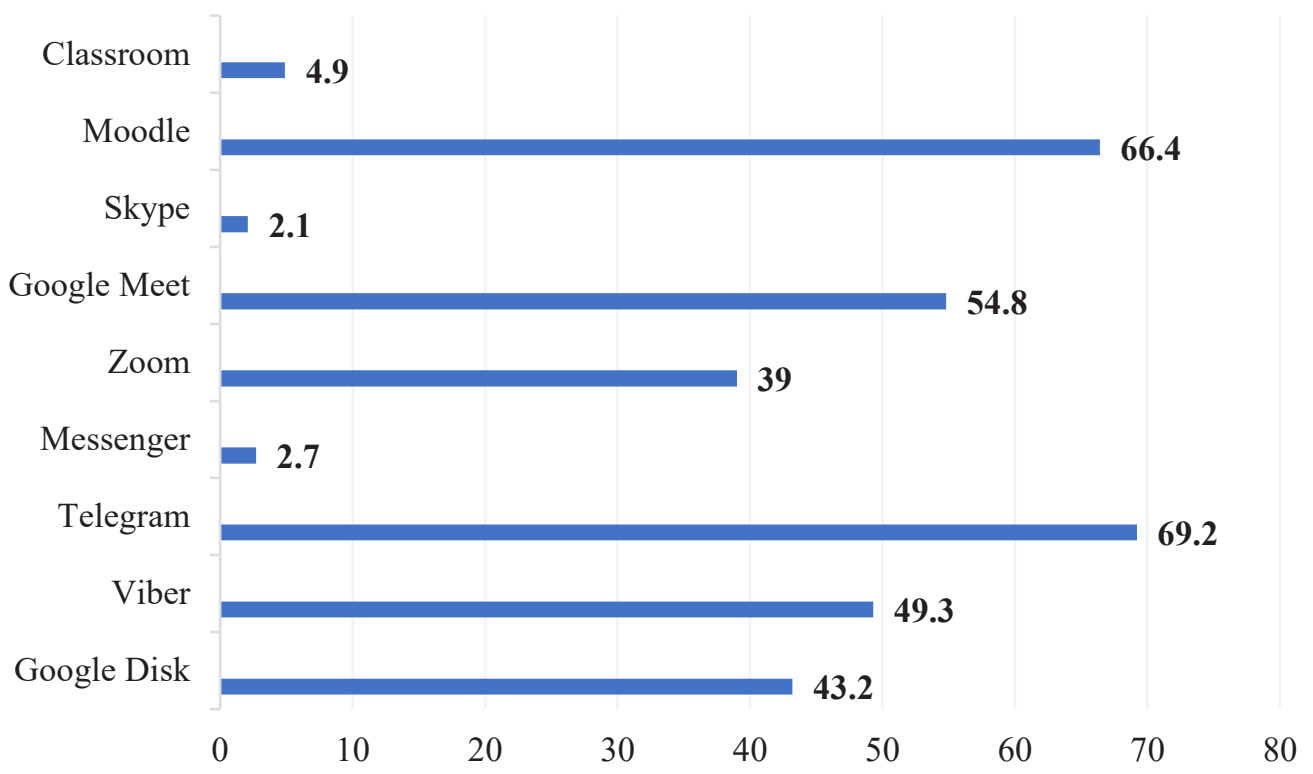

Figure 2. The communicative platforms used by respondents during distance learning, $\%$

Throughout the entire academic year 2020-2021, the HEIs held classes periodically in different modes: some kept to distance learning, some were able to hold classes in a blended mode. Students' opinions on the efficiency of these forms of learning split roughly evenly: $53.4 \%$ (distance learning) and $46.6 \%$ (blended learning). In terms of the relevance and necessity of distance learning under current conditions, $94.5 \%$ of the survey participants admit this format to be necessary, particularly in conjunction with the traditional one. Nevertheless, 5.5\% consider distance learning technologies to be inappropriate in educational process (Fig. 3).

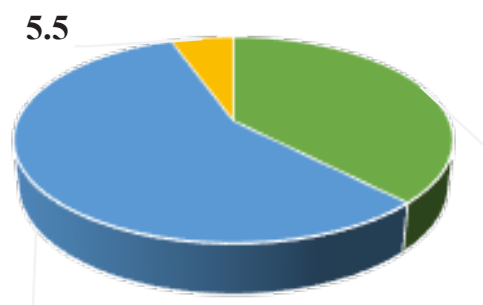

\section{8}

- Very necessary $\|$ Necessary, but combined with conventional education $₫$ Unnecessary

Figure 3. Survey results on the necessity of distance education under current conditions, $\%$

While other educational institutions in the spring of 2020 were only developing plans for the distance learning organisation in an urgent mode, the USFSU moved to online mode of work from the first quarantine day, since the university had already been using Moodle (Modular Object-Oriented Dynamic Learning Environment) for the past several years. This system was initially used to conduct examinations in the form of tests, to make up academic deficiencies, and to re-examine a course of study, etc. Accordingly, all the courses being taught have been provided with appropriate teaching materials. The courses must undergo a certification procedure with a proper document confirming the high quality of the teaching and learning materials. Furthermore, for over 5 years the university has been running advanced training courses for teaching staff in the field of professional and pedagogical activity "Distance learning course development technology. Modern educational technologies". It is based at the Educational and scientific centre for innovative educational technologies and regional education of USFSU [19], which is not only responsible for the smooth functioning of the educational online system, but also carries out educational activities in licensed specialities (educational programmes) at the corresponding educational levels. At the same time, after the imposition of quarantine, a YouTube channel for distance education [20] was created with detailed instructions on using Moodle, since the innovation in the university could not be mastered perfectly at once - both students and teachers faced a lot of questions; Telegram and Instagram chats made it possible to discuss distance learning, seek advice and get answers to any questions. Currently, both students and teachers are making full use of the possibilities offered by Moodle, and 
the global learning platform BigBlueButton, integrated into Moodle, makes it possible to run full-fledged lectures, seminars, discussions, debates, one-to-one questions and so on.

In SSS KCME V.I. Vernadsky TNU, the majority of teachers faced numerous difficulties at the start of the quarantine: how to run the classes, how to assess the students, how to provide them with tasks. Thus, during the first months of the quarantine, the usual platforms (Viber, Telegram, Messenger) were used by the educational process participants. The college held a number of seminars for teachers on how to set up their own virtual classrooms in their courses, leading to the adoption of Classroom platform by the end of the 2019-2020 academic year. For its part, from the beginning of 2020-2021 the Taurida National University (TNU), having created a corporate Google account, organised the switch to the Google Classroom platform. To conduct full-fledged video-meeting sessions, the Google Meet software has been introduced, with both teachers and students joining in through a special link.

On the example of NTU, it should be noted that the institution has been actively introducing distance learning technologies in advance, particularly the Centre for Distance Education was set up back in 2016. The readiness for distance learning in the university was obvious, since even before the world pandemic events, the teachers, mainly of technical specialities, had been using the Moodle system in their work. Thus, they were actually ready for distance learning, as the courses had been fully formed and had already been actively used in the educational process [21]. However, a certain part of the teaching staff, under the new circumstances, was less prepared for online educational activities. In the spring of 2020, teachers used mainly the possibilities of e-mail, social networks such as Viber, Telegram, Messenger and the programmes Zoom, Skype, Discord, etc. to arrange video communication with students. In the next 2020-2021 academic year, due to the accumulated experience, as well as due to the advanced training courses, the university teaching staff was fully aware of and prepared for the implementation of innovative technologies associated with the distance learning organisation. NTU Philosophy and Pedagogy department teachers, apart from the Moodle system (optional), actively used the possibilities of Google supplementing the courses in Classroom with lecture materials, guidelines, test assignments, conducting knowledge checks, providing access to electronic textbooks and so forth. The Google Meet programme has proved to be in great demand, as it has been used to conduct classes.

It should also be mentioned that NUBiP began the distance education implementation back in 2006 by establishing the Centre for Distance Education Technologies, which has developed and tested a range of various models for the application of distance technology elements. Distance learning technologies are used in both internal and external study modes of the university, thereby increasing the quality and accessibility of education. The university has established the NUBiP Educational information portal of Ukraine [22], containing a database of e-courses. All the courses undergo a proper certification before being posted to the portal and are used for both internal and external (distance) study modes. The main advantage of the portal is its provision of high-quality learning material and the possibility of using it anytime and anywhere for the students of all study modes. The portal operates on the basis of the Moodle distance learning platform, providing students with the opportunity to review course materials, perform an assignment, send it for assessment and take an online self-test to check the acquired knowledge. Teachers can design e-learning courses independently and conduct distance learning, send messages to students, distribute the assignments, receive the completed ones and check them, [23]. Notably, to arrange the video communication with students, the teachers worked with user-friendly programmes, such as Zoom.

Figures 4 and 5 illustrate the results of the students' survey on the organisation efficiency (on a 5-point scale) and the level of satisfaction with the distance learning at their educational institution. The implementation was rated as "good" and "excellent" by around $80 \%$ of the students, confirming that online education gained momentum in all of the institutions surveyed; $92.5 \%$ of those surveyed were satisfied (in different ways) with the quality of distance learning.

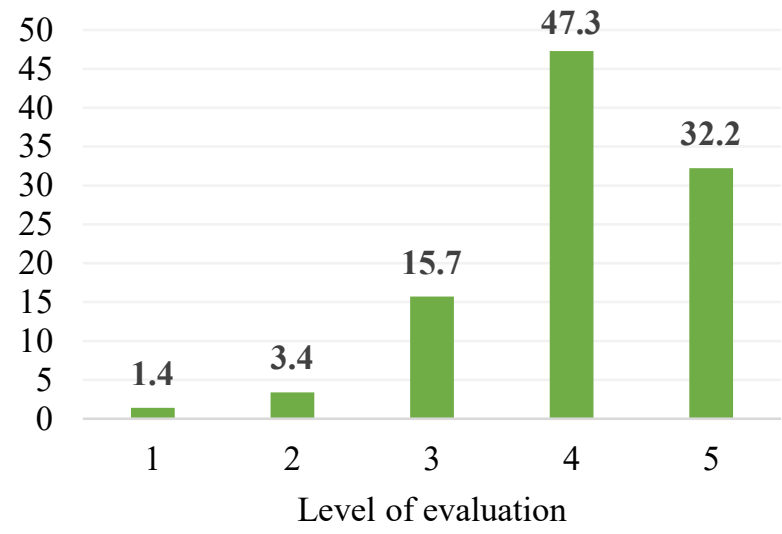

Figure 4. Students' evaluation of the distance learning efficiency in the educational institution, \% 


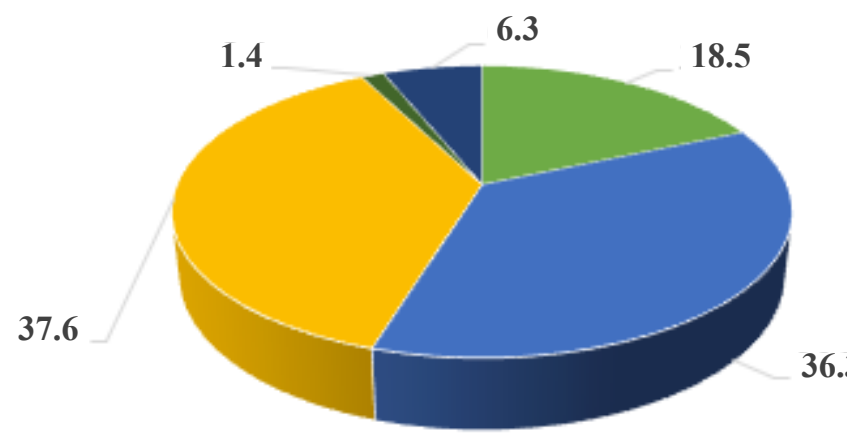

- Very satisfied

- Satisfied

- Generally satisfied, but there are minor complaints

- Completely dissatisfied

- Difficult to answer

Figure 5. Satisfaction rate with the distance learning quality, $\%$

Experts usually focus on the merits and demerits of distance learning $[24 ; 25]$, which include:

- mobility;

- the opportunity to study regardless of time and place;

- accessibility and reusability of learning materials;

- teacher availability;

- the absence of psychological barriers (learning in a calm atmosphere);

- the personal control of the educational process;

- broader and simplified possibilities for learning quality control;

- social equality (equal opportunities to receive education regardless of health or social class);

- globality (the opportunity to study in foreign HEIs regardless of the residence);

- cost-effectiveness;

- self-development opportunity;

- insufficient development of communication, confidence, teamwork skills;

- insufficient practical skills (difficulties in conducting laboratory classes, etc.);

However, it is possible to distinguish typical distance learning components, as a particular component may appear to be both an advantage or a disadvantage for different participants in the learning process (e.g., technical equipment may be a huge obstacle for some, but not for others; besides, what is an advantage for a teacher is not always an advantage for a student and vice versa). Thus, according to the survey, the students consider the greatest benefits of distance learning to be the opportunity to study regardless of time and place $(87.7 \%)$ and the learning materials reusability (54.8\%) (Fig. 6). Moreover, 65.8\% of respondents use distance technologies for self-development (e.g., online courses, not necessarily related to studies, etc.) and had experience of working with distance technologies before the quarantine was declared (Fig. 7).

\section{Repeated use of educational materials \\ Individual control over the educational process \\ Opportunity to study regardless of time and place}

Teacher availability

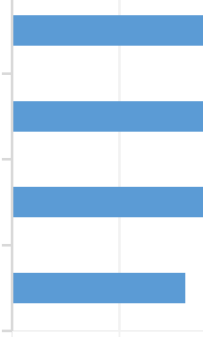

54.8

38.4

32.2
87.7

100

Figure 6. Distance learning benefits according to students, \% 


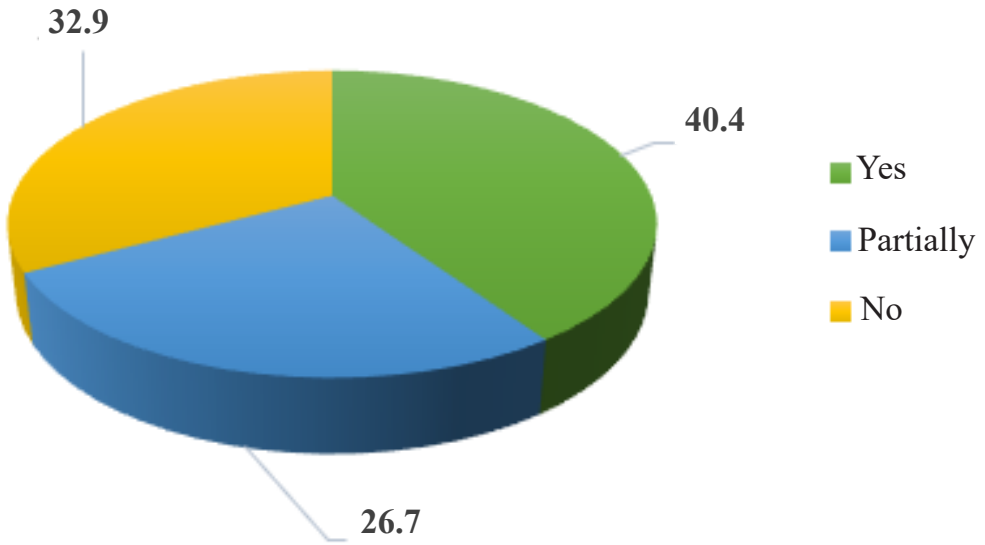

Figure 7. Distance technologies usage by students before the quarantine period, $\%$

Summarising the results of the survey, one should note that the distance learning efficiency, according to the respondents, still largely depends on a subjective factor: the competence and professionalism of the teachers engaged in the process, the motivation of both student and teacher, the availability of pre-designed online courses by the teacher (Fig. 8).
Non-compliance of traditional teaching materials with the
requirements of distance learning
Availability of the effect of student presence in the online
audience
Appropriate level of mastery of information and
communication technology by the teacher
Validity of assessment of learning outcomes
Availability of pre-designed online courses
Use of modern effective means of communication
Student motivation
Teacher motivation
Technical support of the educational process

\section{7}
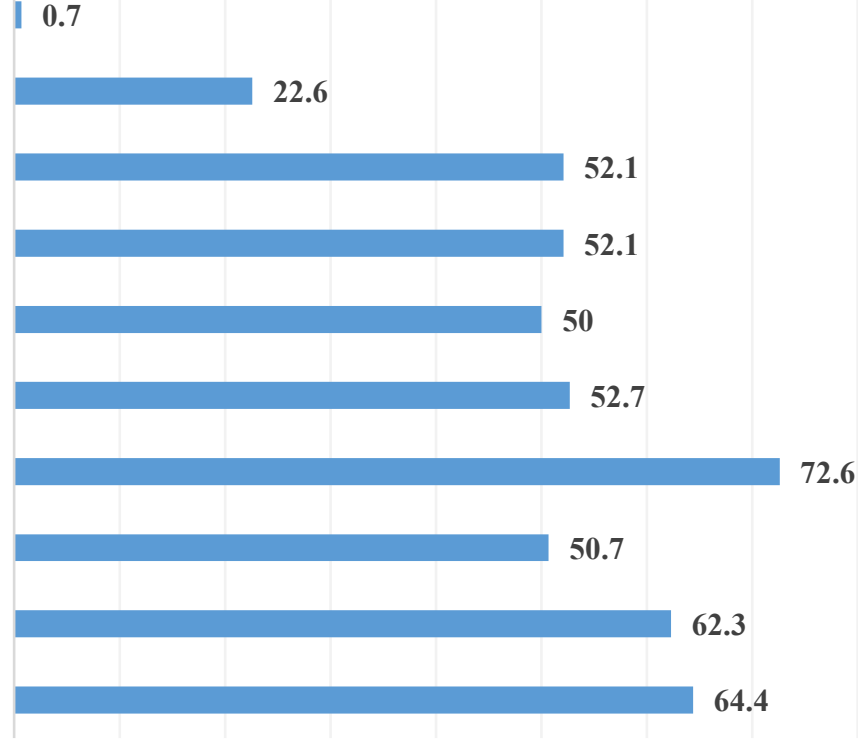

Figure 8. The survey results on the factors affecting the distance learning efficiency, $\%$

Attention should be paid to the fact that the questionnaire included a question about the teachers' attitudes towards online mode of work. The results reveal that $79.5 \%$ of teachers strictly followed the work schedule; $18.5 \%$ followed it partially; and $2.1 \%$ did not follow it at all, which should be taken into account by the authorities of educational institutions. Furthermore, $62.3 \%$ of students consider the teachers' level of using the above-mentioned communication forms to be sufficient, $37 \%$ consider it to be partially sufficient, and only $0.7 \%$ consider it to be insufficient. Moreover, the respondents pointed out that more than $80 \%$ of students' presence during classes depends on the particular course and the particular teacher.

The research results indicate that adaptation to new platforms and devices has taken place in one year of working under quarantine in online mode. Nevertheless, the efficiency of the distance learning process depends not only on the competence of its direct participants (students and teachers) but also on the practical aspects of the process organisation at the level of educational institutions.

\section{CONCLUSIONS}

Thus, the analysis shows that the pandemic has not only accelerated the implementation of distance technologies in the educational process, but has also revealed flaws in the process organisation itself at the level of educational institutions. For the time being, the research field of academics has changed from purely theoretical investigations to the study of practical aspects of distance learning. The study of the distance learning arrangements in various higher 
education institutions has shown that, despite some progress towards the distance technologies implementation, the institution-level organisation requires significant improvement - the establishment of a single platform in the educational institution. The practical investigation by means of a questionnaire survey of students revealed their attitudes towards the necessity of distance education and its efficiency, as well as the factors influencing the quality and performance of distance and blended forms of learning. Currently, all those involved in the teaching/learning process are aware that distance education is firmly entrenched in the educational process. The requirements of time necessitate an organised learning system in an educational institution that can be quickly and easily transformed into different modes: the share of offline or online components being increased or decreased; different organisational models and strategies being chosen according to opportunities, demands and challenges.

\section{REFERENCES}

[1] Law of Ukraine No. 74/98-BP “About the National Programme of Informatisation”. (1998, February). Retrieved from https://zakon.rada.gov.ua/laws/show/74/98-\%D0\%B2\%D1\%80/ed19980204\#Text.

[2] Order of the Ministry of Education and Science of Ukraine No. 466 "On Approval of the Regulations on Distance Learning”. (2013, April). Retrieved from https://zakon.rada.gov.ua/laws/show/z0703-13/ed20130425\#Text.

[3] Armstrong-Mensah, E., Ramsey-White, K., Yankey, B., \& Self-Brown, S. (2020). COVID-19 and distance learning: Effects on Georgia State University school of public health students. Frontiers in Public Health, 8, article number 576227.

[4] Elfirdoussi, S., Lachgar, M., Kabaili, H., Rochdi, A., Goujdami, D., \& Firdoussi, L.E. (2020). Assessing distance learning in higher education during the COVID-19 pandemic. Education Research International, 2020(13), article number 8890633.

[5] Stein, J., \& Graham, R.Ch. (2020). Essentials for blended learning (2nd ed.). London: Routledge.

[6] Nenko, Yu., Kybalna, N., \& Snisarenko, Ya. (2020). The COVID-19 distance learning: Insight from Ukrainian students. Revista Brasileira de Educação do Campo, 5, article number e8925.

[7] Order of the Ministry of Education and Science of Ukraine No.1115 "Some Issues of Distance Learning". (2020, September). Retrieved from http://search.ligazakon.ua/1_doc2.nsf/link1/RE35224.html.

[8] Law of Ukraine No. 2145-VIII “On Education”. (2017, September). Retrieved from https://zakon.rada.gov.ua/laws/ show/2145-19/ed20170905\#Text.

[9] Shtykhno, L.V. (2016). Distance learning as a promising direction of developing modern education. Young Scientist, 6(33), 489-493.

[10] Panchenko, O.A. (2020). Distance education in Ukraine: Problems and aspects. Retrieved from https://vseosvita.ua/ library/statta-na-temu-distancijna-osvita-v-ukraini-problemi-ta-aspekti-361528.html.

[11] Korbut, O. (2013). Distancelearning: Models, technologies, perspectives. Retrieved from http://confesp.fl.kpi.ua/ru/node/1123.

[12] Gavtilova, L., \& Katasonova, Ju. (2017). Theoretical aspects of distance learning in Ukraine. Educological Discourse, 1-2(16-17), 168-182.

[13] Annual report 2019. UNESCO Institute for Lifelong Learning. (2020). Retrieved from https://uil.unesco.org/system/ files/uil_annual_report_2019.pdf.

[14] Learning cities: Drivers of inclusion and sustainability. (2020). Retrieved from https://uil.unesco.org/lifelonglearning/ learning-cities/learning-cities-drivers-inclusion-and-sustainability.

[15] Kuharenko, V.M., \& Bondarenko, V.V. (2020). Emergency distance learning in Ukraine. Kharkiv: Miska drukarnia.

[16] Oleshko, A., Rovnyagin, A., \& Godz, V. (2021). Improving distance learning in the context of pandemic restrictions in higher education. Derzhavne Upravlinnya: Udoskonalennya ta Rozvytok, 1. Retrieved from http://www.dy.nayka. com.ua/?op=1\&z=1936.

[17] Nazarenko, Yu., \& Syrbu, O. (2020). Coronavirus and education: Analysis of the problems and consequences of a pandemic. Retrieved from https://cedos.org.ua/researches/koronavirus-ta-osvita-analiz-problem-i-naslidkiv-pandemii/.

[18] Sukhovirskyi, O.V., \& Liakhnovych, N.O. (2020). Analysis of the results of using the means of organisation of distance learning when training the future primary school teachers under the conditions of quarantine. Scientific Bulletin of Mukachevo State University. Series "Pedagogy and Psychology", 6(2), 30-40.

[19] Official website of the USFSU. (n.d.). Retrieved from https://www.nusta.edu.ua/navchalno-naukov\%d1\%96-centri/.

[20] USFSU. Portal of the distance learning. (n.d.). Retrieved from https://www.youtube.com/channel/ UCYwQE1MyBSaUdV60dgvZDTA/featured.

[21] Official website of the Center for distance and distance learning of the National Transport University. (n.d.). Retrieved from http://do.ntu.edu.ua/.

[22] Educational and information portal of NULES of Ukraine. (n.d.). Retrieved from https://elearn.nubip.edu.ua/.

[23] Official website of the Center for distance learning technologies. (n.d.). Retrieved from https://elearn.nubip.edu.ua/ $\bmod /$ folder/view.php?id=23004.

[24] Myronov, Yu.B. (2020). Advantages and disadvantages of distance learning. Retrieved from https://kerivnyk.info/ perevahy-ta-nedoliky-dystantsijnoho-navchannya. 
[25] Naumova, V. (2020). Advantages and disadvantages: What you need to know about distance learning in Zhytomyr. Retrieved from https://zt.20minut.ua/Osvita/perevagi-ta-nedoliki-scho-varto-znati-pro-distantsiyne-navchannyau-zh-11163782.html.

\title{
Ірина Степанівна Сагайдак', Тетяна Миколаївна Чорна' ${ }^{1}$, Олена Олександрівна Балагура², Валентина Петрівна Биховченко ${ }^{3}$
}

1'Університет державної фіскальної служби України 08205, вул. Університетська, 31, м. Ірпінь, Україна

${ }^{2}$ Національний транспортний університет 01010, вул. М. Омеляновича-Павленка, 1, м. Київ, Україна

${ }^{3}$ Національний університет біоресурсів та природокористування України 03041, вул. Героїв Оборони, 15, м. Київ, Україна

\section{Особливості дистанційного навчання в сучасному українському освітньому просторі: практичний досвід ЗВО}

\begin{abstract}
Анотація. Карантинні обмеження зумовили зростання актуальності дистанційного навчання, а рівень розвитку інформаційних і комунікаційних технологій дав можливість активізувати перехід 3ВО в режим онлайн, що стало оптимальним рішенням в умовах пандемії. Метою роботи $є$ аналіз практичних аспектів дистанційної форми навчання в умовах карантину та виявлення основних чинників, що впливають на його ефективність. Оцінку стану використання дистанційних технологій під час освітнього процесу та оцінку його ефективності проводили шляхом анонімного анкетування в режимі онлайн студентів 4-х закладів вищої освіти: Університету державної фіскальної служби України, Національного транспортного університету, Національного університету біоресурсів і природокористування України та Відокремленого структурного підрозділу Київського коледжу міського господарства Таврійського національного університету імені В.І. Вернадського. У процесі дослідження визначено стан технічного забезпечення дистанційного навчання; з'ясовано рівень і практичний досвід використання дистанційних технологій учасниками навчального процесу; вивчено поведінкові чинники (відвідування занять студентами та дотримання розкладу й тематичних планів викладачами); проаналізовано мотиваційні чинники щодо навчання студентів в онлайн режимі; розглянуто найбільш значущі переваги дистанційного навчання; 3'ясовано ставлення здобувачів вищої освіти до змішаної та дистанційної форм навчання. Обгрунтовано, що організація дистанційного навчання в закладі на базі єдиної платформи є необхідною умовою для забезпечення високої ефективності навчального процесу в онлайн режимі. Практична цінність роботи полягає у використанні результатів опитування для вдосконалення та підвищення ефективності дистанційного навчання на рівні закладу вищої освіти
\end{abstract}

Ключові слова: організація навчального процесу, режим онлайн, карантин, вища школа, анкетування, ефективність онлайн навчання 